\title{
Poetic water images in architecture
}

\author{
U. Kirschner \\ Department of Cultural Studies, Lüneburg University, Germany
}

\begin{abstract}
This essay identifies and examines uses of water imagery in architecture worldwide and through centuries. Architects have introduced imagery in their architectural design since antiquity. This analysis illuminates how the intensive interaction with nature, in this case with water, corresponds to an ever lasting spirit. As Thales of Milet declared: "Water is the source of all things" [1]. This element plays a unique role in the interaction of natural forces. During the Renaissance and particularly during the Baroque age resistance to social alienation was expressed in an abundance of ornamentation; the water foliage and wave formations on the colonnaded capital are analogous to the multitude of water images at times used extensively in lyricism. The water with its varying states of aggregation and mobility inspired many architects to spectacular designs.
\end{abstract}

Keywords: design method, analogies in architecture, nature and architecture.

\section{Introduction}

In all cultures, rituals and symbolism are influenced by the evidence and unlimited abundance of the "element" water. "Water escapes the earth's surface in the form of a spring, moves forward as a river, stands still as a lake and rests in eternal calmness, yet everlasting movement in the form of the ocean. It transforms itself to ice or to steam, it ascends through evaporation while it descends as rain, snow or hail ... it hovers as a cloud ... it is colourless, yet can take on all colours ... it is formless, yet can adapt to any given form; it is soft, yet stronger than stone. It creates contours in the form of valleys, coastlines and grottos" [2]. In mythology and legends, the oceans and rivers are inhabited by gods and goddesses, spring and water nymphs, sirens and mermaids. The water source, the spring, symbolizes the tears, blood and milk of Mother Earth. In the 
atmospheric lyricism of the 18th century, metaphors such as mentioned were often portrayed.

Poets employ water as a metaphor for abundance and power, strength and movement, temptation and danger; an idyllic, on the other hand, uses water colour to create a peaceful and balanced atmosphere. According to Goethe "Poetry reveals the mysteries of nature and attempts to solve these mysteries through imagery" [3]. Water is one of the most archetypal images with which poetry attempts to do this [4].

\section{The influence of water on space}

"When water comes in contend with solid elements, is when it becomes imaginative. It creates forms, whirl pools and veils, drops and streams, rivulets and veins around every stone it comes in contact with. It endlessly swirls about the solid element, nestles itself up to it and hollows out a space within it" [5]. In the Wells cathedral the nave is connected to the main hall of the clerical chapter by a waterway, which divides itself into two different levels. This English church is otherwise designed according to rules of Gothic tradition with the influence of Roman cubes and Gothic curves. The attributed bold entryway has been guiding the course of a multitude of clerics for centuries. The hand-modelled stairway, constructed according to the architectural prerequisites, subtly bridges the altitude difference of the nave level and the foyer level, fig. 1. Its function as an entryway into the chapter hall seems secondary to the beautiful image of flowing water that it creates."

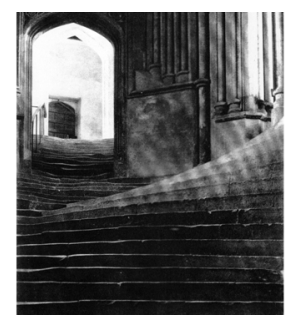

Figure 1: $\quad$ Cathedral of Wells [6].

Water appears to have left its footprints in the form of a hollow in the middle of each step. This illusion gives the steps of Wells a flowing rhythm, like that of waves [7]; their beauty lies in their resemblance to the natural movement of the water.

An increase in kinetic energy creates vibrations on the waters' surface. Waves are the result of the complex dance between water, wind and time. Antoni Gaudi built a school on the Sagrada Familia plot in Barcelona based on the idea of using stone to create wave sequences. Gaudi's choice of the wave as the main motif of his design was religiously inspired; it is a temporary apparition. Additionally, the wave offers practical construction advantages: the curved structure increases the weight-bearing capacity of the facade as well as the 
ceiling, which was built in the form of the sine curve, fig. 2.1. Thus, it was completely unnecessary to use any pillars or structural bearing walls in the interior space. The exterior is constructed in highly porous brick, suitable to the weather in northern Spain.
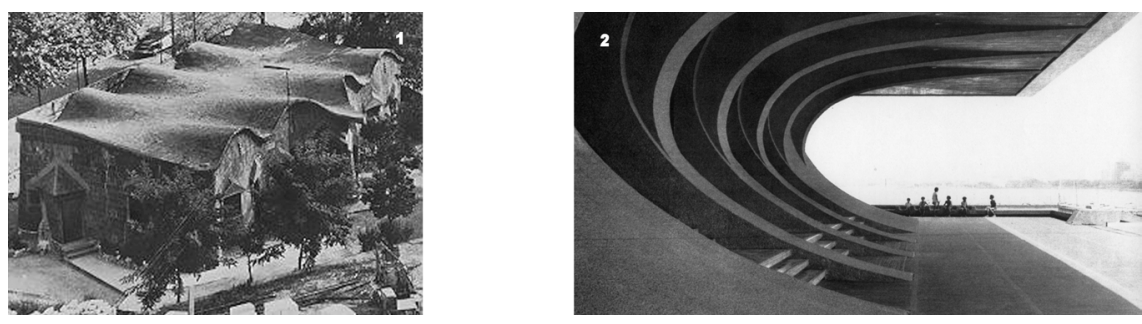

Figure 2: 1. School in Sacrada Familia, Gaudi, 2. Opera, Philippines, Locsin [8].

In contrast to Gaudi's romantic portrayal of waves, the Philippine architect Leandro of Locsin designed the Theatre of Mount Makiling in Los Banos (1976), as a possible precursor for a storm tide of Homeric dimensions:

"Like the storm of relentless wind.. ./. . .excites the flood and creates the breaking waves of the thunderous open sea..." [9].

As an architect, Locsin worked with similar expressiveness as Homer on the design of the theatre and opera house in which he had previously worked as singer and stage designer [10]. For this building, he chose the form of a threatening, somersaulting wave complemented by its mirror image in a flat pool of water, situated in front of the building, fig. 2.2. The inherent strength of the construction resembles a dancer, who requires every muscle in order to float as light as a feather across the stage. Time frozen in an image is the major factor characterizing these artistic portrayals. Time is frozen in the form of an edifice.

\section{Water mythology - fantasies of space}

A mirrored water image creates the centre of the 17th century Schah mosque in Isfahan. The mosque courtyard is laid out in the shape of cross. Four liwane or arched entryways symbolically support the canopy of heaven above the indoor courtyard and border the pool in its centre, fig. 3.1. The water mirrors the surrounding edifices and vaults. The mirror image reconstructs both the horizontal and vertical axes of the edifice, while at the same time creating a third vertical axis, connecting water, heaven and earth. The nature of the orthogonal grounds keeps the visitor on the centre line. The central entrances through the liwane into the courtyard lead the visitor to the focal point of a "kaleidoscopic vision", which reveals the infinity of creation [11]. Many languages use only one word for the terms: soul, image and shadow. An image is considered to be a 
living representation and embodies the soul of its bearer. Much more value is attached to it than to the human body itself [12].
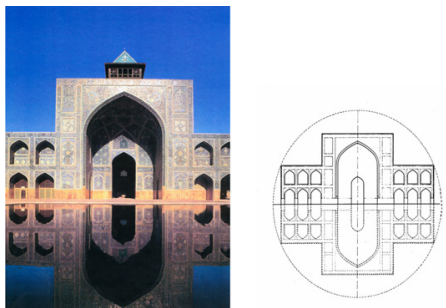

Figure 3: 1 Isfahan, Liwane;
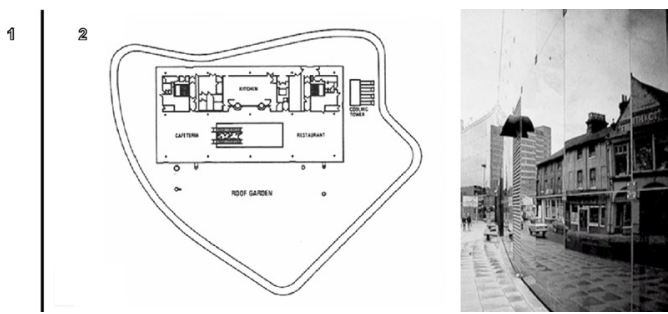

2. Insurance Building, Ipswich, Forster [13].

"Narkissos fell in love with his own mirror image while drinking water from a spring. Because he could not attain this image, he was devoured by desire and transformed into a flower, the narcissus" [14]. In contrast to this well-known metamorphosis water can also provide a living dimension to lifeless matter, for example a building. Norman Forster chose, consciously or unconsciously, the smooth surface of pond water, as his design motif for the Willis Insurance Building in Ipswich, 1974, fig. 3.2. The amorphous floor plan is reminiscent of a lake that one can only walk around and can only set foot upon when frozen; the building is circumnavigated by traffic as if it were an island. The facade of the building is a mirror image of the surrounding city life, creating a magical point of attraction. Much like the mirroring waters of a garden, it seems to be the eye of the city.
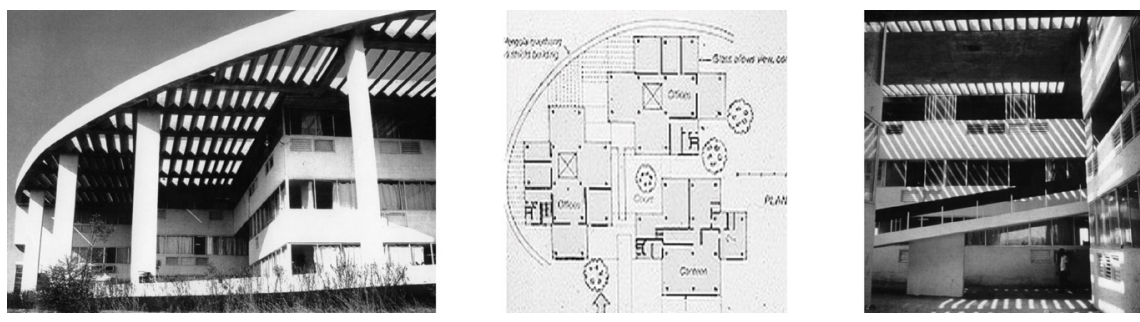

Figure 4: Admission Building, India, Correa [15].

From 1967-1972, Charles M. Correa built the administration building for the Electronic Corporation of India in Hyderabad, fig. 4. His idea was to create a sober and demystifying replication of the sea. Correa analyzed the ecological conditions in the depths of the sea and put his findings to work by creating an office building with optimal climatic conditions. The shape of the roof is amorphous, similar to Forster's floor plan. Individual, crystalline-shaped threedimensional spaces are situated just under the roof. For cooling purposes, pools of water were installed above these closed spaces. These pools reflect sunrays, intensifying the comparison to a stilted sea surface with a rocky reef shimmering below. The rest of the roof consists mostly of segment bars, which partly cover 
the courtyard and partly jut out, partially shading the underlying rooms. The interesting dance between light and shadows suggests the atmosphere of the underwater world. With these and other simple methods, Correa created the prerequisites for a salubrious climate without using any energy-wasting facilities.

\section{Ice-, snow- and fog-architecture}

Water exists in fluid form, in solid form or as steam. Under normal pressure conditions, at $100^{\circ} \mathrm{Celsius}$ water transforms into steam, at $\mathrm{O}^{\circ} \mathrm{Celsius}$ it freezes, and at $4^{\circ} \mathrm{Celsius}$ it possesses the highest density. Ice is water in its partcrystalline, part-solid aggregate state. Unlike ice, snow is not frozen fluid but rather water, crystallized through condensation. Water differs from most substances in that the transformation from the fluid to the solid state involves a reduction of density. The result of this is that ice floats on water, but it can also display explosive force when it is generated from water.
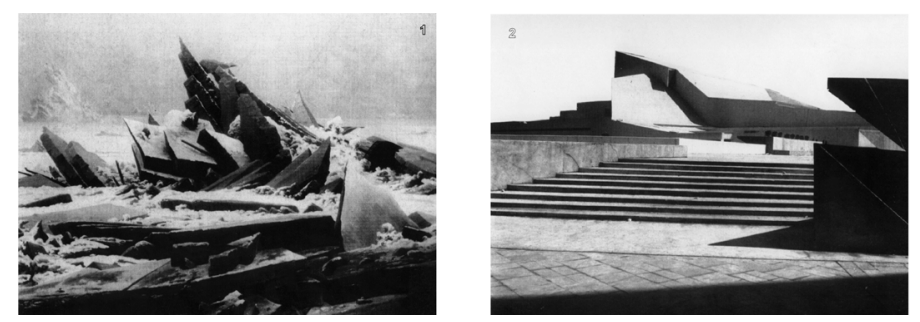

Figure 5: 1. Im Eismeer, C.D. Friedrich; 2. Opera, Skopje, Tange [16].

A well-known ice motif is Le Corbusier's chapel roof of Ronchamp, modelled in the form of a voluminous, one-meter-thick snowdrift. Caspar David Friedrichs' famous painting "In a sea of ice", fig. 5.1, with its steeply erected, overlapping ice floes, served as the main atmospheric inspiration for Hamburg's utopian cities, designed by students of various universities, among others [17]. Deconstructivists, in particular, especially like to implement this repertoire of forms. The Slovenian architecture group "Studio 7" constructed such a work of art in an Opera house in Skopje, located in the southern province of Macedonian, fig. 5.2. Following an earthquake that destroyed the city, Kenzo Tange worked out a concept for the restoration of the city in 1968. He situated the new opera house adjacent to the Vardar River, directly in the centre of the city. The opera house was built from 1972-1981 and is considered one of the most important post-war constructions of the country [18]. The architectural team described the edifice as follows: "Motion and vitality have been created by the purity of form and diversity of space reaching from the interiors to the exteriors. The play of light and shadows on the white walls additionally enhances the idea and expression of the space" [19]. In their design of the opera house, the architects adopted the tangible drama of Friedrich's painting, with its virtual cracking and breaking sounds of shattering ice floes, and accentuated it with white colour. In 
the preceding examples, we have considered the forms that water can create as well as interpreted the movement and various states of water.

Glass is a building material which is similar to water and ice in many ways. The physical correlation between glass and water lies in the fact that glass is solidified fluid.
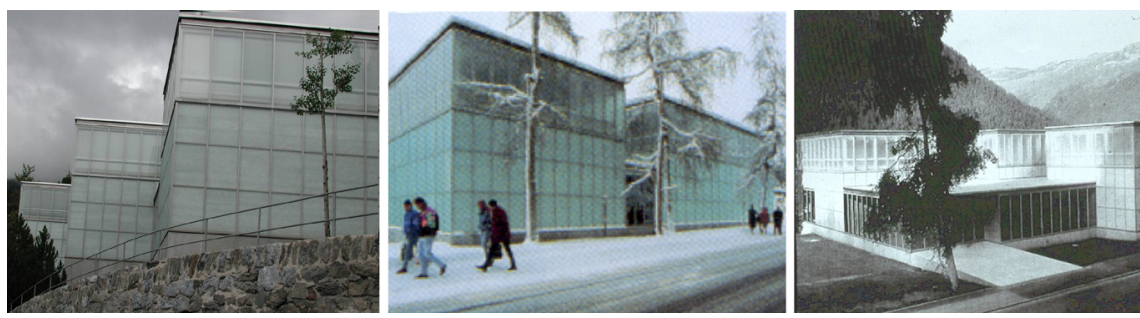

Figure 6: Kirchner Museum, Davos, Gigon and Guyer [20].

The entire facade of the Kirchner museum building complex in Davos, Graubünden (Northern Switzerland) is seemingly constructed entirely of glass and gives the impression of water in its aggregate states, fig. 6. The Zurich architects, Anette Gigon and Mike Guyer, erected the museum in 1992, which is comprised of four massive cubicles, the exhibition rooms and the entry hall. All constructional components, with exception to the entryways, are panelled with matted, i.e. cauterized glass plating. The fibrous surface structure of the insulation material shimmers through the glass plating, leaving the impression of a glittering, non-transparent ice surface. With its diffuse reflections, the house seems to adapt to the seasons like a chameleon. It is as if the building puts on a cape of fog when the mountain summits are buried in the clouds; when the landscape is covered in snow, the glass front shimmers in a light shade of green, like glacier ice; the glass cubicles glimmer in the falling rays of sunlight. The roof of the museum with its diffuse reflecting glass-splinter surface, complements the building facade. Despite the amount of glass incorporated into its facade, the building offers only a minimal view from the outside into its interiors; similarly, from the inside, one can see only little of the surrounding high mountain landscape. The exhibition rooms exclude the outside world. Only three-meter-high small, angled ceiling windows provide indirect light exposure, allowing the daylight to stream in at a side angle. Traditional ceiling windows are too readily darkened by falling snow. The raw concrete walls of the connecting hall correlate to the outside world. Correspondingly, the sculptures are intentionally situated to seemingly be a part of the surrounding mountain landscape [21].

\section{The relationship between water and location in architecture}

Since primeval time man has dreamed of controlling the forces of nature. C. N. Ledoux designed a home for the Director of the Department of Water Control in the form of a pipe connected to a massive underground foundation, 
fig. 7.1. Retained by the pipe walls, the wild mountain water of the Loue River rushes through the house. This design was never built and was often criticized because it did not meet the prerequisites of a residential home. Nevertheless, it was a project that fully incorporated the force of water and the spectacular image is still frequently referred to today.

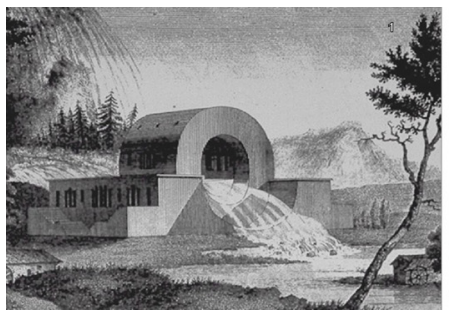

Figure 7: 1. Livinghouse, F. L. Wright [22].
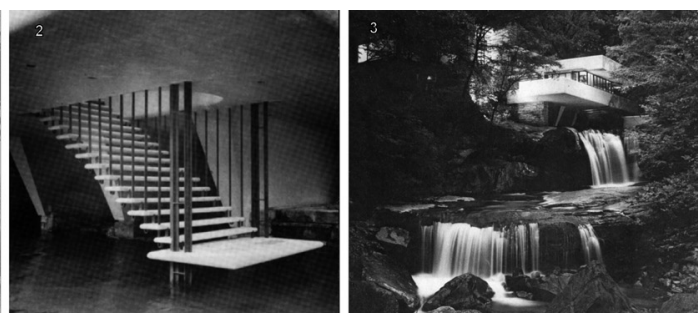

Ledoux;

2. and 3. Fallingwater house,

The "Falling Water" house from Frank Lloyd Wright is the perfect example of a man-made imitation of the phenomena of water and nature. Wright built this vacation home above a waterfall, a constant cascade of falling and flowing water over massive rock formations ending in the Ohiopyle Valley below. Using glass and concrete, he seemingly extended the waterfall in an upward direction, fig. 7.3. From the foot of the waterfall by day, the whitewashed basins seem more like falling water and the dark glass components look like water-covered stones. At night, the opposite effect occurs. The reflection of artificial lighting makes the glass seem bright and pattering, while the basin edges disappear in the darkness. In the winter, the terraces lose their gleam next to the snow-covered stone landscape and now-frozen water. In the winter months, not only the visual impression but also the functionality of the house is reduced to its stone towers and glass volumes. This project was constructed using only horizontal surfaces, i.e. the surface of water, and perpendicular lines, i.e. falling masses of water. Wright avoided the use of diagonals where possible; not even one handrail or banister exists in the entire house. The stairways are suspended from vertical poles or built between two parallel walls, fig. 7.2 [23].

My personal choice for the theme of an architectural project was the encounter between water and stone. On the northern island of Germany called Helgoland, the ocean is the dominant force versus the red sandstone cliffs. A boarding school for children suffering from allergies was to be built on a strip of man-made land between the northern jetty and the edge of the cliffs. The exposed setting and the unique location of the windy island offered the perfect architectural stage. The complex is composed of five residential houses, a combined school building and sports hall, as well as a stone garden and an underwater garden. The architecture and layout of the complex reflects the emergence of Helgoland, fig. 8. Through a crack in the stratum layers, water poured into the salt masses lying deep below the surface. Over time, the osmotic pressure pushed the new red sandstone layers from southwest to northeast. At the 
$27^{\circ}$ angle of inclination found today, the move stopped as the water had become saturated with the accumulated salt masses [24]. In the design the stone garden is a ground relief created by the exposed stratum layers. Within the five boarding houses, the rock layers form a great mass, raising up the oceans here in the form of a skin of glass and opening the gate to the underwater world. The "underwater garden" is also used by a neighbouring biology institution. With its aquariums, it serves as a space for experiments and exhibitions, illuminated by the light shining through the skin of glass above it. This "skin of glass" also serves as the floor for observers to walk on as they steal a view into the underwater world. The boarding school children have access to this virtually allergy-free world through the connecting multi-purpose rooms of the residential building. The garden serves as an entryway to the joint boarding school and sports hall. It is as though this building were a cascade on the mountainside making the stratification and crystalline quality visible. The boarding school is built as a stilted terrace above the sports hall with a splendid view of the ocean beyond the roofs of the boarding houses. The school courtyard is situated on the roof of the sport hall and bordered by carefully placed flood lights.
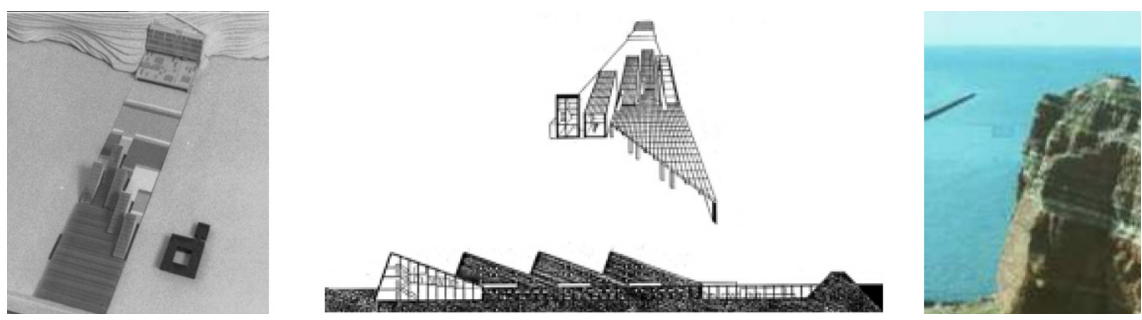

Figure 8: Design for a boarding school, Helgoland, Kirschner, photo of the cliff.

\section{Conclusion}

Metaphors, which act as ideas for architectural designs are analysed in this paper. In nearly the same way as styles pictures can act as leitmotif, their perception touches the depths before moving the surface [25]. Architecture ought to address more than functional constraints; and instead engage in and adapt an interactive exchange with other arts and issues. While painting, sculpture and literature may depict - but do not really have to - architecture, like music, has to create its own topics. This is the principle task of architectural design.

Here in particular the element of water with its figurative polarity may serve as a metaphor for mythic death as tide and at the same time as the source of life itself. The church like a ship with Christ as its captain on the rough sea is an essential Christian image. In the use of religious symbols in sacred buildings or the representation of operational sequences in functional buildings their design idea becomes obvious. This holistic approach is described by Walter Benjamin this way: "Humans have a primal urge, to correlate the objects and phenomena of their world" [26]. 


\section{References}

[1] Thales-Zitat 6. Jh. v. u. Z., ed. Böhme Hartmut Kulturgeschichte des Wassers, Frankfurt a. M. pp. 52-53, 1988,

[2] Böhme Hartmut (eds). Kulturgeschichte des Wassers, Frankfurt a. M., pp. 12-13, 1988

[3] Trunz v. E. (eds). Maximen und Reflektionen, No. 904, Goethes Werke, Hamburg 1948, XII, 493.

[4] Blume Bernhard, Existenz und Dichtung, Frankfurt a. M., p. 152, 1980

[5] Schwarz Rudolf, Von der Bebauung der Erde, Heidelberg, p. 53, 1949

[6] Peter Sager, DuMont Kunst-Reiseführer Südengland Köln p. 227, 1989

[7] Sager Peter, DuMont Kunst-Reiseführer Südengland, Köln, pp. 251-252, 1989

[8] 2.1. Zerbst Rainer, Antoni Gaudi, Köln, p. 214, 1987; 2.2. Polites Nicholas, The architecture of Leondro V. Locsin, New York + Tokyo S 108, 1977

[9] Homer, "Ilias", in Bernhard Blume (eds), Existenz und Dichtung, Frankfurt a. M., p. 150, 1980

[10] Udo Kultermann, Architekten der Dritten Welt, Köln, p. 157-158, 1980

[11] Henry Stierlin, Isfahan, Orbis Terranun, Genf, pp. 78-83, 1976

[12] Martin Ninck, Die Bedeutung des Wassers im Kult und Leben der Alten, Darmstadt, p. 58, 1960

[13] 3.1. Stierlin Henri, Isfaha, Genf, pp. 112, 83, 1976; 3.2. ChaslinFrancois, Hervet Frédérique, Lavolou Ammolle, Norman Forster, Paris, pp. 56-57, 1986

[14] Ovid, Metamorphosen 3, Frankfurt a. M. 1998.

[15] Cantacuzino Sherban, Charles Correa, Singapore, pp. 36-37, 1984

[16] 5.1. Friedrich C. D., Im Eismeer, www.Onlinekunst.de/september/05 eismeer_friedrich.jpg; 5.2. Kultermann Udo, Zeitgenössische Architektur in Osteuropa, Köln, p. 198, 1985

[17] Held-Schäfer Andrea, in Bauwelt 40/1987, Dissertation, Gütersloh, pp. 1508-1509

[18] Kultermann Udo: Zeitgenössische Architektur in Osteuropa, Köln, pp. 197-198, 1985

[19] Udo Kultermann: Zeitgenössische Architektur in Osteuropa, Köln, p. 200. 1985

[20] Kirschner Ursula, 2002; Binder Hans, $d b$, Stuttgart, pp. 64, 4, 8/1994

[21] Binder Hans, $d b$, Stuttgart, pp. 64-69, 8/1994

[22] 7.1. Vidler Anthony, Claude-Nicolas Ledoux, Massachsetts, p. 320, 1990; 7.2., 7.3. Hoffmann Donald: Frank Lloyd Wright's Fallingwater, New York, p. 94, 1978

[23] Hoffmann Donald: Frank Lloyd Wright's Fallingwater, New York, p. 59, 1978

[24] Geologisches Jahrbuch, Reihe A, Heft 62

[25] Barchelard Gaston, Poetik des Raumes, München, p. 17, 1975 
152 Eco-Architecture: Harmonisation between Architecture and Nature

[26] Benjamin Walter, Die Lehre vom Ähnlichen, in: Siegfried Unseld, Zur Aktualität Benjamins, Frankfurt a. Main, p. 23, 1972 